THE OPTIMIST 
Stanford Studies in Middle Eastern

and Islamic Societies and Cultures 


\section{THE OPTIMIST}

A Social Biography of Tawfiq Zayyad

\section{Tamir Sorek}




\section{STANFORD UNIVERSITY PRESS}

Stanford, California

(C) 2020 by the Board of Trustees of the Leland Stanford Junior University.

All rights reserved.

No part of this book may be reproduced or transmitted in any form or by any means, electronic or mechanical, including photocopying and recording, or in any information storage or retrieval system without the prior written permission of Stanford University Press.

Printed in the United States of America on acid-free, archival-quality paper

Library of Congress Cataloging-in-Publication Data

Names: Sorek, Tamir, author.

Title: The optimist : a social biography of Tawfiq Zayyad / Tamir Sorek.

Other titles: Stanford studies in Middle Eastern and Islamic societies and cultures.

Description: Stanford, California : Stanford University Press, 2020. Series: Stanford studies in Middle Eastern and Islamic societies and cultures | Includes bibliographical references and index.

Identifiers: LCCN 2020008448 (print) | LCCN 2020008449 (ebook) | ISBN 9780804797474 (cloth) | ISBN 9781503612730 (paperback) | ISBN 9781503612747 (ebook)

Subjects: LCSH: Zayyad, Tawfiq.| Politicians—Palestine—Biography. | Nationalists-Palestine-Biography. | Poets, Palestinian Arab-Biography. | Arab-Israeli conflict—History—2oth century. | Palestine-Politics and government-1948-

Classification: LCC DS126.6.Z39 S67 2020 (print) | LCC DS126.6.Z39 (ebook) | DDC 320.54095694092 [B]—dc23

LC record available at https://lccn.loc.gov/2020008448

LC ebook record available at https://lccn.loc.gov/2020008449

Cover photo: Tawfiq Zayyad on the Knesset Podium

Cover design: Rob Ehle 